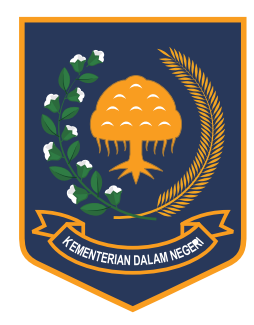

JURNAL BINA PRAJA

e-ISSN: 2503-3360 | p-ISSN: 2085-4323

Accreditation Number

21/E/KPT/2018

http://jurnal.kemendagri.go.id/index.php/jbp/index

\title{
THE DifFICULTIES IN THE HANDOVER OF HOUSING INFRASTRUCTURE, FACILITY, AND UTILITY in THE Greater Bandung AREA
}

\author{
Anita Vitriana \\ Badan Penelitian dan Pengembangan Daerah (BP2D) Provinsi Jawa Barat \\ Jl. Kawaluyaan Indah Raya Number 6, Kota Bandung, Indonesia
}

Received: 17 May 2019; Accepted: 19 July 2019; Published online: 8 November 2019

DOI: $10.21787 /$ jbp.11.2019.149-157

\begin{abstract}
There were some problems in the handover of housing Infrastructure, Facilities, and Utilities (PSU (Prasarana, Sarana dan Utilitas)) by developers to local governments. Since the issuance of Minister of Home Affairs Regulation Number 9 of 2009, only small numbers of housing PSU have been handed over by the housing developers to the local government. The objective of this study was to explore some problems related to the handover of the housing PSU which located in Greater Bandung Area, both from the developers and the local governments' sides. This study used a descriptive - qualitative approach. The primary data collection was conducted with an in-depth interview method to the fourteen developers experienced in housing development in the Greater Bandung Area and three local government officials. The secondary data was collected through the online news along with the regional regulations related to the handover of housing PSU in the districts/cities level of the Greater Bandung Area. The primary and secondary data were analyzed by Qualitative Content Analysis. The study showed that problems came from both developers and local governments' sides. The developers believed that the bureaucracy for the housing handover was complicated, while the local governments stated there were inconsistencies between the approved site plan and the built PSU. The local governments also have not had mature planning for the housing PSU's operation and maintenance after the handover. Thus, as the organizer of housing affairs, the governments need to immediately reform the PSU planning and management in terms of its provision, financing, and maintenance.
\end{abstract}

Keywords: Difficulties, the Handover of Housing Infrastructure, Facilities and Utilities, Local Government, Developers.

\section{INTRODUCTION}

Facilities, Infrastructure, and Utilities (PSU (Prasarana, Sarana dan Utilitas)) are the prerequisites in fulfilling the housing needs. As mandated by Law Number 1 of 2011 on Housing and Settlement Area, the PSU is the infrastructure needed to provide livable housing. Based on Law Number 1 of 2011, infrastructure is defined as the basic physical infrastructure of housing area, with a certain standard to provide livable, healthy, safe, and comfortable housing. Facilities are defined as the housing area facilities to support the social, cultural, and economic life, while public facilities are defined as supporting facilities for housing area services. Infrastructures at the minimum include roads, drainage, sanitation, and drinking water; facilities at the minimum include places for worship and open green space; public utilities at the minimum include electricity networks and telephone networks.

Housing PSU, by its nature, is a public good. As such, it should be provided by the government to be used by the public at no charge. This is hard to be held in developing countries. In this case, the government has a shortage of budgets and human resources to provide and manage public goods (Lesmana, 2017, p. 42). For this reason, the government as the state organizer opens opportunities for both individuals and legal entities to contribute to the provision of public goods, one of which is related to the management of the provision of housing PSU. But problems will arise if the provision and management of public goods are

\footnotetext{
* Corresponding Author

Phone : +62812 20178600

Email : avitriana@yahoo.com
} 
exclusive and competitive (Rahutami, 2010, p. 2).

Law Number 1 of 2011 mandates that the government have to manage infrastructure, facilities, and public utilities for housing and settlement areas. The provision of the PSU is carried out by the government, local government (Pemda), and/or the public. In this case, the construction of a PSU can be carried out by all parties with the prerequisites (as explained in article 47) that the completed PSU must be handed over to the district/city government in accordance with the provisions of the laws.

In an urban context, where housing development generally involves a lot of private developers, the provision of PSU, would also be carried out by developers along with housing developments. In line with Law number 1 of 2011, Minister of Home Affairs Regulation number 9 of 2009 on Guidelines for the Handover of Infrastructure, Facilities, and Utilities for Housing and Settlement in the Local Regions also mandates the handover of PSU for housing settlements from developers to the local governments to ensure the continuity of maintenance and management of housing PSU in the housing and settlement areas. As such, the maintenance of infrastructure, facilities, and utilities built by the developer will be the responsibility of the developer before the handover to the local government, while after the handover, the maintenance responsibility will be held by the local government.

The handover of the management of housing PSU to the local government restores the nature of the housing PSU to its original function as public goods, which should be open for public use. However, lately, many housing PSU are exclusive and not open for public use. This exclusivity in the use of the housing PSU contradicts the principle of public goods. However, when the provision of housing PSU were not carried out by the government, and its management and maintenance, for one reason or another, were not carried out by the government due to difficulties to handover the housing PSU, the access limitation to the use of PSU in housing areas to people outside the area is considered to be acceptable.

The handover problems mostly occur in urban housing built by developers. There are many problems with the maintenance of housing PSU because the Local government is unable to repair them (since the developer has not handed it over), while the developer has not maintained the housing PSU after the completion of the housing development project.

The housing PSU is not a stand-alone structure. Besides being public goods, the PSU is also part of an integrated housing infrastructure network connected to the surrounding. In a broader context, restrictions on the access and the usage of housing PSU, especially infrastructure and utilities in the form of networks, ultimately have an impact on the fragmentation and segregation of infrastructure networks, inequality in PSU services, and inefficiencies in providing housing infrastructure (Hudalah, Winarso, \& Woltjer, 2007, p. 508).

Bandung Metropolitan Area as the third-largest urban area in Indonesia is also experiencing similar problems. Bandung Metropolitan Area was formed by five cities/districts covering the entire area of Bandung City and Cimahi City, half of Bandung District and West Bandung District, and a small part of the Sumedang District. It experienced rapid growth in housing since early 1980. Like other urban areas, Greater Bandung Area experiences with very high housing growth, and many of them built by private housing developers. No less than 1,000 new housing units were built in the Greater Bandung Area over the last 40 years. However, there were only small numbers of housing PSU that has been handed over to the government. In Bandung City, out of 591 developers has built housing estates but only 20 developers who have handed-over their PSU (Soreang Ekspres, 2019, p. 1). In Bandung District, only 24 out of 343 housing estates had handover their PSU. The number of housing estates that have handed over their PSU in Bandung District is less than 10\%. In Cimahi City, which was established in 2001, only two developers have handed over their PSU to the Cimahi City government until the beginning of 2019. (Mugni \& Vetra, 2019, p. 1). Likewise, in KBB (established in 2007), out of 113 housing estates, there were only 4 who have handed over their PSU since the last data collection in 2016 (Ragam Daerah, 2018, p. 1).

Why were only a few handovers of PSU from the housing developers to the local government even though the regulation was already enforced for ten years? Referring to Minister of Home Affairs Regulation Number 9 of 2009, the problems of handover of housing PSU should never happen. However, these problems do exist in the fields. Thus, it is important to understand the actual problems faced by the developers and the government in the handover process.

Problems of the handover of housing PSU has been discussed in previous studies, but generally, it was discussed based on localities, such as Pratama (2013, p. 1) and Nurhakim \& Pandamdari (2018, p. 4) focuses on Tangerang City, Tamsir (2012, p. 8) on Makassar City, Sadewo (2017, p. 8) on Semarang City, Rizal (2009, p. 1) on Surabaya City, Damayanti (2011, p. 1) on Banjarbaru City, Nugrahandika \& Pramono (2017, p. 1) on Yogyakarta City, and 
Supriyanto (2017, p. 1) on Sidoarjo District. There were few discussions on handover of housing PSU in the scope of large urban areas from the views of the stakeholders involved in the handover process. This study is important because residential developments in the metropolitan area are very fast, and it has a broad impact, especially related to the inequality in the provision and utilization of housing infrastructures. A study on housing developers (as the one conducting the development) and the local government (as the recipient of the PSU) needs to be performed to find out more about the handover problems.

In the metropolitan area, each district/city has its local regulations as the implementation of Minister of Home Affair Regulation Number 9 of 2009. As such, the objective of this study was to identify and analyze various issues in the handover of housing PSU in districts/cities in the Greater Bandung Area to pinpoint the main problem. This study provided an overview of the problems and offer policy recommendations for the government for an effective and smooth handover of housing PSU, especially those in the Greater Bandung Area.

\section{MeThoD}

This study used a descriptive method with a qualitative approach. The use of a qualitative approach was intended to obtain a more in-depth description of the implemented policies. In this case, the qualitative study is more concerned with the "process" aspect than "results." The relationship of the studied parts will be much clearer if observed from the process (Moleong, 2017, p. 11). By using a qualitative approach, this study aimed to provide a comprehensive explanation and understanding of the problems to the handover of the housing PSU (Pratama, 2013, p. 12).

Data collection was carried out by in-depth interviews of private developers who held housing development in the Greater Bandung Area and the local governments. The sources were selected using a purposive sampling technique, with the criteria of private developers having more than five years of experience in developing land on a fairly large scale for a residential purpose (more than ten hectares).

Primary data were collected in four months, between July and October 2018, comprised of fourteen representatives of developers, two of whom are known as pioneers of housing developers in the Greater Bandung Area. Information obtained from the fourteen interviewees is considered sufficient because it has met the data saturation. Interviews were also conducted to three district/ city government official as the receiver of the handover of the housing PSU in the means of data triangulation. Open-ended questions were used in the interviews and then written in data transcripts.

Secondary data obtained through Online Newspaper documents related to the handover of housing PSU in the Greater Bandung Area, as well as literature studies of regional regulations as the implementation of Minister of Home Affairs Regulation Number 9 of 2009 in the district/city.

Further analysis was carried out on the data. In this section, a content analysis approach was conducted to interpret the data obtained from the interviews, as well as using coding techniques and grouping keywords to analyze the four regional regulations at the district/city level related to the handover of the housing PSU. The study location includes Bandung City, Bandung District. West Bandung District, and Cimahi City. Sumedang District was excluded because, at the time of the study, the Sumedang regional regulations regarding the handover of the housing PSU were not finalized.

\section{RESULTS AND Discussion}

The results and discussion divided into two sub-sections, namely: 1) review of the districts/ cities regulations on the handover of housing PSU and 2) analysis of the results of interviews with the local government and developers on the implementation of the regulation on the handover of housing PSU.

\section{A. Review of the Districts/Cities Regulations on the Handover of the Housing PSU}

Regional regulations related to the handover of housing PSU in the district/city are the implementation regulations of the Minister of Home Affairs Regulation Number 9 of 2009. The four regulations governing the handover of the PSU in the Greater Bandung Area (minus Sumedang) are based on the Local Regulation of Cimahi City Number 10 of 2017 on the Provision, Handover of the Housing Infrastructure Utilities and Facilities from Developers to City Government, West Bandung District Local Regulation Number 13 of 2013 on the Handover of Infrastructure, Facilities and Utilities of Housing and Settlement Areas, Local Regulation of Bandung District Number 6 of 2012 on the Procedures for Handover of the Housing Infrastructure, Facilities and Utilities from the Developer to the Local Government of Bandung District, and Local Regulation of Bandung City Number 7 of 2013 on the Provision, Handover, and Management of Infrastructure, Facilities and Utilities of Housing and Settlement Areas.

\footnotetext{
The Difficulties in the Handover of Housing Infrastructure, Facility, and Utility in the Greater Bandung Area

Anita Vitriana
} 
Referring to Minister of Home Affairs Regulation Number 9 of 2009, all regional regulations on the handover of the housing PSU in the study area stated that the handover could be in some stages or at one time. The handover of the PSU shall be carried out no later than one year after the maintenance period under the approved site plan. The Regulation of Cimahi City added that changes to the master plan or site plan could be held without changing the approved plan and must be agreed by $50 \%$ of the owners of housing plots.

Regarding the area dedicated for the housing PSU, only the requirement for the public cemetery land is specified in the district/city regulations, which is $2 \%$ of the land value or the land area, although it has not specified in Minister of Home Affair Regulation Number 9 of 2009. Bandung District and Cimahi City specify the land dedicated for the cemetery at $2 \%$ of the NJOP value of the land developed by the developer, while $\mathrm{KBB}$ and Bandung City specify the cemetery land at $2 \%$ of the area developed by the developer. The land for the cemetery can be provided collectively in locations with a proper spatial plan.

For other PSU designation, only Bandung City and Cimahi City specified the required percentage. Bandung City requires the developers of landedhouse to provide PSU at $40 \%$ of their land. The commercial facilities are at a maximum of $10 \%$ of the effective land (not including the area designated for the housing PSU). Cimahi City requires apartment and landed-house developers to provide $40 \%$ of housing PSU area, along with some details of the percentage of housing PSU with the emphasis of the provision of land for gardens and open green space of $20 \%$.

The handover of the housing PSU shall be conducted by following the handover procedures set out in the regional regulation. Bandung City and Bandung District determine the general, technical, and administrative requirements for the handover of housing PSU. KBB has a general and administrative handover procedure. Slightly different from other regions, Cimahi City did not specify the handover procedure in detail. Cimahi City has just created a breakthrough in the regulation on the handover of the housing PSU, by requiring the handover as part as the issuance of the construction permit, with the release of rights from the developer after a feasibility assessment by the verification team and minutes of handover is made. This provision can be one of the technical solutions to some handover problems of housing PSU which are often overlooked by the local government because the housing development itself takes a long time and the technical agencies cannot always monitor it directly.
Generally, the handover process in the districts/cities is the same. Bandung District, KBB, and Bandung City specify the handover procedure in their regional regulations. There will be a verification process on the administrative, technical, and general requirements. For housing PSU that did not pass the verification process, Bandung District allows the developer to repair the housing PSU within one month, while the Bandung City allows the developer to repair it within three months. If all requirements were met, the Minutes of Verification (BAP) then submitted to the regional head and Minutes of Handover (BAST) was signed by the developer and the regional head. Slightly different from other districts/cities, the handover process in KBB was not just based on the request, but also based on a periodic stocktaking. This periodic stocktaking might be one of the best monitoring systems on the provision of housing PSU to anticipate problems and deviations during the constructions.

he regional regulations have two procedures for an abandoned PSU. First, the local government issues a letter to the developer to repair the housing PSU and hand it over to the local government. If the developer cannot fulfill it, the developer can provide a letter stating their inability and the local government would then issue a Minutes of Handover (BAST) as the base to record it as the government asset. Second, for PSU with an unknown developer, the local government may bring the case to court to get the court decision to declare that the developer cannot be found. The court decision, power of attorney, and notarial deed are the base to register the right over the housing PSU with BPN. Certificate on the right of housing PSU is then issued by BPN and the housing PSU is listed as regional assets. The Regional Head may assign the housing PSU to the local agency (SKPD) to manage the housing PSU.

\section{B. Analysis of the Handover of Housing PSU from the Point of View of the Developer and the Local Government}

Out of the fourteen developers interviewed, thirteen stated that there were plenty of problems in the handover process. The majority of developers stated that the main problem with the handover was the long bureaucracy, messy administrations, unclear procedures, and ever-changing requirements. Two of the developers who are the pioneer in the Bandung area have been facing the handover problem in almost all the districts/cities in The Greater Bandung Area.

One of the sources stated that even though the handover process was recently through the online single submission system, but it did not cut through 
the red tape. When the handover documents were filed and found to be incomplete, the follow-up between the officer and the developer were held outside of the system and were not well documented. As a result, the process of completing the handover documents was not organized and it had to be repeated several times, resulting in uncertainty in the timeline needed for the handover. Another developer stated that some of the handovers took him more than three years and it has not completed yet.

Other developer revealed that often the length of time needed for the handover was not written in the official documents, because when the handover was validated, usually the date was adjusted to show a shorter length of the process. The developer also stated that the hand over tend to be faster when it is favorable for the local government. When the handover of the housing PSU increases the assets and not burdening the local government with many expenditures, the local government will hasten the handover process. However, if the handover of the housing PSU incurs maintenance and other expenses, the process tends to be long and difficult. Similar observation is found in a study by Rizal $(2009$, p. 5$)$, the researcher noted that there are a mutual influence and relations between the political actors and the economic actors in the development of policies on the handover of housing PSU benefiting certain groups, and the lack of enforcement by the local government in the implementation of the handover policy.

One of the developers stated that the length of time for the handover process was due to the slow internal process of the local government. When there is a change of officials in the middle of the handover process, sometimes the developer must re-submit the documents. In line with this statement, one of the developers stated that one of the problems that he had was caused by the change of nomenclature and authority of the unit responsible for the handover, which resulted in the loss of the documents and the process had to be restarted from the beginning. The longer it took for the handover process, the problem will become increasingly long and difficult, because of the change of personnel from both parties (developers and local governments) will cause the process to be back to square one. The lack of clarity and length of the handover process ultimately affected the developer.

For developers, the long process of the housing PSU handover is very detrimental. The developer stated that the length of the handover process weighed heavily on them because as long as the housing PSU was not handed over, the developer was legally responsible for its maintenance. It is common for residents to demand the developers to continue to maintain the housing PSU, while the developer no longer has a budget for it. Usually, before the developer started the handover process to the local government, they made improvements and repairs to the housing PSU. However, because the process is very long and complicated, by the time the local government started the field survey, the housing PSU already sustained some damage. At that time, the developer no longer has a budget for repairs at that location. Which in turn hinder the handover process.

The problems on the housing PSU handover process were often associated with the slow adoption of handover regulation within the local government itself. Bandung City stipulated the handover of new PSU in 2013 by issuing Bandung City Local Regulation Number 7 of 2013 on the Provision, Handover, and Management of Infrastructure, Facilities, and Utilities for Housing and Settlement Areas. One of the obstacles to the handover process in Bandung City was that Local Regulation Number 7 of 2013 mandates that developer constructing a housing complex of over 5,000 square meters must handover a minimum of 40 percent of the housing PSU to the Bandung City Government. The regulation also stipulates that developers who had not handover their PSU were allowed to do so within the specified period (two years). The regulation would apply to such developers if they did not handover their PSU within the specified timeline. In reality, some housing area in Bandung City were more than decades-old, and housing PSU had not been handed over. As such, since 2013, there was no handover because many housing areas have less than $40 \%$ area dedicated to PSU. The developer cannot handover the housing PSU, and the Bandung City Government cannot accept the housing PSU. To solve this problem, the local government of Bandung City is currently revising the regional regulation on PSU handover (Soreang Ekspres, 2019).

Bandung District issued Local Regulation Number 6 of 2012 on the Procedures for the Handover of Housing Infrastructure, Facilities, and Utilities from the Developer to the Local Government of Bandung District. The regulation specified that the requirements for the handover of the housing PSU are that it must be conducted after its construction, the maintenance period is complete, and the housing PSU must be in a good physical condition. The problem occurred because developers often cannot repair the existing PSU when it is about to be handed over. This regulation also explains that an administrative sanction in the form of a suspension of the permit to build new housing for housing developers who have

\section{The Difficulties in the Handover of Housing Infrastructure, Facility, and Utility in the Greater Bandung Area}

Anita Vitriana 
not yet handed over the housing PSU. However, in the permitting procedure, this is often overlooked because the licensing agency is not the agency that manages the handover of the housing PSU. In this case, the local government acknowledged that it is necessary to reform the internal administration (Radar Bandung, 2019, p. 1).

West Bandung District (KBB) issued Local Regulation Number 13 of 2013 on the Handover of Infrastructure, Facilities, and Utilities for Housing and Settlement Areas, and its implementation guideline in the form of Regent Regulation Number 6 of 2016 to accelerate the handover of the housing PSU. One of the government's efforts to manage the handover is to conduct data collection on the housing areas. Based on the results of the 2016 data collection, many developers in KBB have not yet handed over their PSU. Meanwhile, housing construction in KBB continues to emerge to meet the urban community's demand for a place to live (Ragam Daerah, 2018, p. 1).

Cimahi City issued Local Regulation Number 10 of 2017 on the Provision, Handover of Infrastructure, Facilities, and Utilities (PSU) of Housing and Settlement Areas from Developers to the City Government as the implementation regulation of Minister of Home Affair Regulation Number 9 of 2009. Like other districts/cities in the Greater Bandung Area, Cimahi City also experienced a vacuum handover of housing PSU. In addition to the regional regulations that have just been enacted, the government also considered lack of internal planning system. When the government permits the developer to carry out housing development, the government should have a future plan on the budget, maintenance, and management of the housing PSU. When all the housing PSU have been handed over, the government must be able to provide the budget for the cost of repairs of the entire settlement area. This is what the Local government seems not to have prepared and planned carefully in its longterm planning and budgeting (Nugraha, 2018, p. 1).

Besides the difficulty of the handover procedure for the housing PSU, Tamsir (2012, p. 68) stated that another reason why developers sometimes did not immediately handover the housing PSU to the local government is for the residents' satisfaction and the protection of the consumer rights, since the local government often do not manage the housing PSU adequately. But this is not the only reason for the late handover. On the other hand, the local government stated that sometimes the handover problems came from violations committed by housing developers. The violation was in the form of a change in the designation of an area, which was originally intended for the housing PSU but instead changed into housing units. The government, in this case, cannot do much because the government can act against these violations if the construction of the housing PSU has been completed and has been handed over.

One of the developers stated that some residents would prefer that repair and maintenance be held by the developer. Some of the developers took advantage of this opportunity by having an estate management concept as the housing management, which includes managing security, cleanliness, waste, and other physical improvements to the housing PSU, with the consequence that the residents still had to pay an environmental management contributions (IPL). This practice solves the management problems, but the housing PSU which should function as public goods can be shifted into private goods because the community and developers maintain the housing PSU assets without involving the government. In this case, the handover of the housing PSU was not only viewed from the handover, but more than that, the government's duty was to think about matters relating to the maintenance, planning, and structuring of the city (Damayanti, 2011, p. 32).

Only one developer shared a successful experience in PSU handover. However, until now the developer is still disbursing maintenance costs for the housing PSU. The government only maintains the main road infrastructure functioning as a public corridor. The partial division of financing and maintenance of the housing PSU was complained by the residents because they do not receive the same treatment while they were paying the same tax. The case where the residents and the developer still pay maintenance costs was mentioned by another developer who stated that even though the developer had handed over the housing PSU that they had built, they still required to make the payments of street lights (PJU) and road repairs.

The party that is most disadvantaged from the various problems of the housing PSU handover are the residents. When the handover process is hampered, it is common for developers to neglect their maintenance responsibilities. As a result, the residents have to manage it independently. Nugrahandika \& Pramono (2017, p. 300) explained that the problem of the housing PSU handover would cause additional costs for the residents to obtain services that should be available from their housing area. When the maintenance of the housing PSU was taken over by residents, they eventually acted unilaterally by closing the access of the housing PSU from the usage of the public because they were the one who 'responsible' for the maintenance of the housing PSU. If this continues, it will ultimately 
affect the exclusivity of the use of the housing PSU. Another disadvantage is that the local government cannot intervene or assist in its management. If the local government assisting the housing area, they can be accused to violate the law due to trespassing to other people's area without permission (Adikara, 2016, p. 2).

From the perspective of the local government, the process of housing PSU handover was not just about receiving of physical assets. The handover of the housing PSU must be guided by the handover regulation. The local government receives the handover of housing PSUs that have met the general, technical, and administrative requirements. The general requirements include locations following the site plan that has been approved by the local government, the licensing documents, and technical specifications. The technical requirements are in accordance with the provisions of the laws related to housing and settlement development. The administrative requirements include site plan that has been approved by the local government, Building Construction Permits (IMB), Building Use Permits (IPB), and letters of the release of land rights from the developer to the local government (Tamsir, 2012, p. 32). The release of land rights may have different interpretation. A developer stated that one district/city required the release of rights in the form of the handover of the land ownership title (SHM), but in other districts/cities it only needs a notary deed of the release of rights.

With these various problems, the handover of housing PSU to local governments were not easy to implement, because there were some differences in perceptions or views between the developers and the governments. On the one hand, the local governments were concerned about the slow handover of housing PSU from the developers, while on the other hand, the developers considered the local governments' handover procedures to be very complicated (Purwanto, 2010, p. 20). Problems in the handover of infrastructure, facilities, and utilities by the developer to the local government have a negative impact for the government, including the loss of trust from the public since the government unable to guarantee the provision and maintenance of public facilities (Rizal, 2009). Another impact was the loss of regional assets, which may reduce regional income (Pratama, 2013, p. 12; Hanny, 2011 , p. 1). As stated by one of the sources from the local government who acknowledged that every asset must have value, and if the assets that should be owned by the government were not taken and managed by the government then the government would lose the value of its wealth.
In the case of housing PSU that has long been abandoned by the developers, Minister of Home Affairs Regulation Number 9 of 2009 mandates that the Local government can take over the abandoned PSU by making minutes of the acquisition of the housing and settlement PSU. However, the implementation of the regulation is still difficult because it involves the legal aspect.

Rizal (2009, p. 5) explained the cause of the government's lack of enforcement, one of which was due to the lack of earnestly of the local government in dealing with the issue of the handover of the housing PSU. This is evidenced by the facts that many developers have not handover the housing PSU of their old housing areas, and no sanction was imposed on them, even when the occupancy rate was high, and the construction had exceeded the requirements to handover the housing PSU. To be able to apply strict sanctions, the government must be prepared in law enforcement tools, as explained by Supriyanto $(2017$, p. 11). The government must first be able to prepare a direct or indirect, preventive, and repressive, as well as internal and external set of supervision instruments. The government's capacity and integrity are needed, without them, inconsistencies, and weak law enforcement will continue to happen (Woltjer, 2014, p. 9).

\section{Conclusion}

The problems of the handover of housing PSU in The Greater Bandung Area seems to stem from the difficulty of implementing the handover regulations without mature planning and implementation management system. Minister of Home Affairs Regulation Number 9 of 2009 has explained in detail how the handover procedure should be carried out, the cities/districts also have issued regulations on the implementation of handover to facilitate the technical implementation in their area. However, there were many problems, which were mainly caused by the inadequacy of the local government in planning, implementing, and supervising the housing PSU. This led to the failure of the handover process (such as the incompatibility of housing PSU with its site plan and permits), difficulties for developers to immediately handover the housing PSU, difficulties for the local government to implement appropriate sanctions, and the lack of adequate budget to manage the housing PSU when the housing PSU is handed over to the local government. The steps that need to be taken by the local governments to fast-track the housing PSU handover process are as follows:

\footnotetext{
The Difficulties in the Handover of Housing Infrastructure, Facility, and Utility in the Greater Bandung Area

Anita Vitriana
} 
1. The local government should prepare a detailed and robust housing area development plan, along with the standards for providing the housing PSU to ensure that it does not become a burden when it is handed over to the government. The plan should include the calculation of the carrying capacity of the environment along with the master plan of infrastructure system, as well as the budget plan for the management and maintenance of the housing PSU. The developers then must follow what has been planned by the government. Thus, the implementation and supervision process will be easier and more effective.

2. The local government may issue the technical guideline for the housing PSU handover in the form of Regional Head Regulation.

3. The local government must carry-out periodic monitoring and evaluation during the construction process so that various irregularities can be immediately identified, solutions can be sought, or sanctions may be imposed for those who intentionally commit violations. If the monitoring, physical supervision, and law enforcement functions have been carried out properly, the issue of non-compliance with the provision of housing PSU that hinders the handover process can be avoided in advance.

4. The government should be ready with the appropriate budget and maintenance management system when the housing PSU is handed over. The reward and punishment mechanism through incentive and disincentive schemes can also be applied if the government already has a good framework of housing PSU handover system and management. This reinforces the importance of increasing the capacity of the government as the conceiver, regulator, and supervisor of housing and settlement development, to provide regulations and plans for an inclusive and equitable housing PSU.

\section{ACKNOWLEDGMENT}

The author expresses the deepest gratitude to the Regional Research and Development Board of West Java Province for all moral and material support in carrying out this study. The author also expresses the highest appreciation to Delik Hudalah, Ph.D., Jehansyah Siregar, Ph.D., and Dr. Eng. Arif Sarwo Wibowo for his assistance during this research.

\section{REFERENCES}

Adikara, G. P. F. (2016). Evaluasi Implementasi Peraturan Daerah Number 7 Tahun 2010 tentang Penyerahan Prasarana, Sarana dan Utilitas pada Kawasan Industri, Perdagangan, Perumahan, dan Permukiman di Kota Surabaya. Kebijakan Dan Manajemen Publik, 4(3), 2. https:// doi.org/ISSN 2303 - 341X

Damayanti, I. W. (2011). Peran Pengawasan Pemerintah Daerah dan Implikasinya Pada Pembangunan Kawasan Perumahan. Focus, 1(1), 31-70.

Hanny. (2011). Analisis Faktor-Faktor yang Mempengaruhi Terhambatnya Penyerahan Fasilitas Umum dan Fasilitas Sosial Perumahan di Kota Depok. Institut Pertanian Bogor. Retrieved from https://www.google.com/url?sa=t\&rct=$\mathrm{j} \& \mathrm{q}=\&$ esrc $=\mathrm{s} \&$ source $=$ web $\& \mathrm{~cd}=2 \& \mathrm{ved}=2 \mathrm{a}-$ hUKEwifwLGkyqniAhWLLo8KHW9IBooQFjABegQIAxAC\&url=http \%3A\%2F\%2Frepository.sb.ipb.ac.id\%2F1470\%2F5\%2FR42-05-Hanny-Pendahuluan.pdf\&usg=AOvVaw3wnooWsbrDUYhQIqaQv1Sn

Hudalah, D., Winarso, H., \& Woltjer, J. (2007). Peri-urbanisation in East Asia: A new challenge for planning? International Development Planning Review, 29(4), 507. https://doi.org/10.3828/ idpr.29.4.4

Lesmana, R. A. (2017). Meta-Theory: Kebijakan Barang Publik untuk Kesejahteraan Rakyat. Jurnal Ekonomi Dan Kebijakan Publik, 8(1), 42. Retrieved from https://www.google.com/ url? sa $=$ t\&rct $=\mathrm{j} \& \mathrm{q}=\&$ esrc $=\mathrm{s} \&$ source $=$ web \&c$\mathrm{d}=2 \& \mathrm{cad}=\mathrm{rja} \&$ uact $=8 \& \mathrm{ved}=2$ ahUKEwjZ jtXkn6niAhXTfX0KHf14D0wQFjABegQIBRAC\&url=https $\% 3 \mathrm{~A} \% 2 \mathrm{~F} \% 2 \mathrm{Fjurnal}$.dpr. go.id $\% 2$ Findex.php $\% 2$ Fekp $\% 2$ Farticle $\% 2$ Fdownload\%2F697\%2F534\&usg=AOvVaw2LWigw5CvKIgKr6elPrVwk

Moleong, L. J. (2017). Metodologi Penelitian Kualitatif. Bandung: PT. Remaja Rosdakarya.

Mugni, Y., \& Vetra. (2019, January 31). Revisi Perda PSU Perumahan Targetkan Rampung April. Fokusjabar.Go.Id, p. 1. Retrieved from https:// fokusjabar.co.id/2019/01/31/revisi-perda-psu-perumahan-targetkan-rampung-april/

Nugraha, A. (2018). Kesadaran Pengembang Buruk, DPUPR Kota Cimahi Turun Tangan. Fokusjabar.Go.Id, p. 1. Retrieved from https://fokusjabar.co.id/2018/10/26/kesadaran-pengembang-buruk-dpupr-kota-cimahi-turun-tangan/ Nugrahandika, W. H., \& Pramono, R. W. D. (2017). Lokalitas Pengaturan, Prasarana, Sarana dan Utilitas Umum Perumahan di DIY : Tipologi dan Permasalahannya. In Seminar Nasional Space 
\#3 (p. 300). Denpasar: Universitas Hindu Indonesia. Retrieved from http://digilib.mercubuana.ac.id/manager/t!@file_artikel_abstrak/ Isi_Artikel_404662076334.pdf

Nurhakim, M. A., \& Pandamdari, E. (2018). Pemenuhan atas Sarana dan Utilitas pada Perumahan Subsdi Mutiara Puri Harmoni Rajeg Tangerang Menurut UU Number 1 Tahun 2011 tentang Perumahan dan Permukiman. Jurnal Hukum Adigama, 1(1), 1-24.

Pratama, A. R. (2013). Faktor-Faktor Penghambat Pelaksanaan Penyerahan Prasarana, Sarana, dan Utilitas (PSU) Perumahan di Kota Tangerang Selatan. Jakarta. Retrieved from https://www. google.co.id/url?sa=t\&rct=j\&q=\&esrc=s\&source $=$ web \&cd $=1 \&$ cad $=$ rja $\&$ uact $=8 \& v e d=2 a-$ hUKEwi5jMPAvI_hAhXMwI8KHVylBEsQFjAAegQIBBAC\&url=http \%3A\%2 F \% 2 Flib.ui.ac.id $\% 2$ Fnaskahringkas $\% 2$ F 2 015 - 09\%2 FS 4 4945-Ad a m\%2520 Rizki\%2520Pratama\&usg=AOvVaw3hvPNFwtFyD3ELP6KPqtAo

Purwanto. (2010). Analisis Kebijakan dalam Pengadaan Fasilitas Sosial dan Fasilitas Umum di DKI Jakarta. Universitas Indonesia. Retrieved from https://www.google.com / url? sa =t\&rct $=$ j\& $\mathrm{q}=\&$ esrc $=s \&$ source $=$ web $\& c d=1 \&$ cad $=$ rja $\&$ uact $=8 \& v e d=2 a-$ hUKEwj3h8rxsPngAhWN4 H MBHcCYCH kQFjAAegQIABAC\&url=http \%3A\%2F\%2 Flib.ui.ac.id \% 2 Ffile $\% 3$ Ffile $\% 3$ Ddigi tal\%2 F20236871-T\%252028756-Analisis\%2520kebijakan-full\%2520text.pdf\&us$\mathrm{g}=\mathrm{AOvV}$

Radar Bandung. (2019, January 26). Hanya 30 Persen Pengembangan di Kabupaten. Radarbandung.Id, p. 1. Retrieved from https://www.radarbandung.id/bandung-raya/2019/01/26/hanya-30-persen-pengembangan-di-kabupaten/

Ragam Daerah. (2018). Pengembang Perumahan di KBB 'Diplototi.' Ragam.Co, p. 1. Retrieved from https://ragam.co/2018/03/13/pengembang-perumahan-di-kbb-diplototi/

Rahutami, A. I. (2010). Infrastruktur sebagai Ba- rang Publik dan. Semarang. https://doi. org/10.13140/RG.2.2.32682.93120

Rizal, M. S. (2009). Ekonomi Politik Penyerahan Fasum dan Fasos Oleh Pengembang Perumahan Kepada Pemerintah Kota Surabaya. Jurnal Politik Muda, 3(2), 5. https://doi.org/ISSN 23028068

Sadewo, Y. W. (2017). Peran PPAT dalam Penyerahan Fasilitas Umum dan Fasilitas Sosial oleh Pengembang Perumahan kepada Pemerintah Kota Semarang. Universitas Islam Sultan Agung Semarang. Retrieved from https://www. google. $\operatorname{com} /$ url?sa=t\&rct=j\&q=\&esrc=s\&source $=$ web $\& c d=1 \& c a d=r j a$ uact $=8 \& v e d=2 a-$ hUKEwiY-8vpy6niAhVLqY8KHT4IAGsQFjAAegQIABAB\&url=http\%3 A\%2F\%2Fjurnal. unissula.ac.id\%2Findex.php\%2Fakta\%2Farticle\%2Fview\%2F1778\&usg=AOvVaw2sRpGTvvTCPbjut4rBSH8E

Soreang Ekspres. (2019, February 6). Revisi Perda PSU Perumahan. Jabar Ekspres, p. 1. Retrieved from http://jabarekspres.com/2019/revisi-perda-psu-perumahan/

Supriyanto, B. (2017). Kebijakan Penyerahan Prasarana, Sarana dan Utilitas di Kabupaten Sidoarjo. Jurnal Kebijakan Dan Manajemen Publik, 5(1), 11. https://doi.org/10.21070/jkmp. v5i1.811

Tamsir, R. (2012). Tinjauan Yuridis terhadap Fasilitas Sosial (Fasos) dan Fasilitas Umum (Fasum) pada Perumahan dan Kawasan Permukiman di Kota Makassar. Universitas Hasanuddin. Retrieved from https://www. google. com $/$ url?sa $=t \& r c t=j \& q=\& e s r c=s \&-$ source $=$ web $\& c d=2 \&$ cad $=$ rja $\&$ uact $=8 \& v e d=2 a-$ hUKEw jPs u GYzKn i A h V Jv 48 K H T p M D kIQFjABegQIARAC\&url=http \%3A\%2F\%2Frepository.unhas.ac.id\%2Fbitstream $\% 2 \mathrm{~F}$ handle \%2F $123456789 \% 2$ F $6272 \% 2 \mathrm{~F}$ S K R I P S I \% 25220 P E R D A TA-\%2520RIFKY\%2520TAMSIR.pd

Woltjer, J. (2014). A Global Review on Peri-Urban Development and Planning. Jurnal Perencanaan Wilayah, 25(1), 1-16.

\footnotetext{
The Difficulties in the Handover of Housing Infrastructure, Facility, and Utility in the Greater Bandung Area

Anita Vitriana
} 